\title{
DERIVAS CRÍTICAS DE LA CIUDAD POSTMODERNA: SUEÑO COLECTIVO Y CONTRAESPACIO
}

\author{
Carlos TAPIA \\ Departamento de Historia, Teoría y Composición Arquitectonicas. Universidad de Sevilla \\ https://dx.doi.org/10.12795/astragalo.2016.i21.10
}

Fig. 1 Boulevard du Temple, verano de 1838, Paris, 3ra. de Arrondissement, Daguerrotypie.

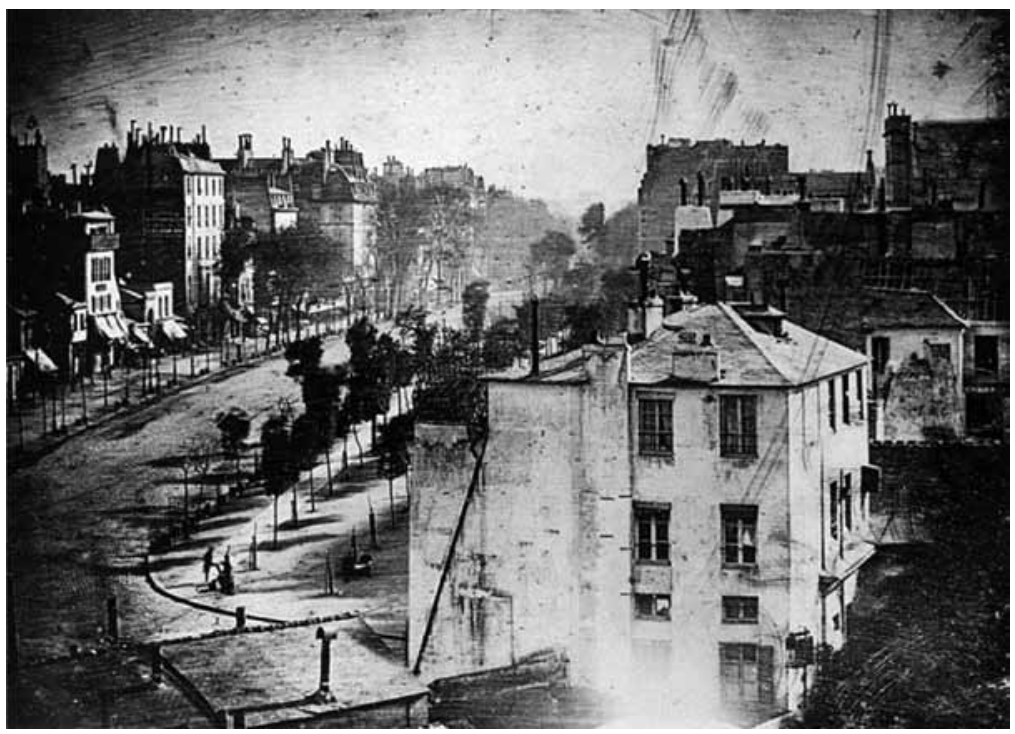

\section{ACTO 1. QUID.}

Que la población de las ciudades griegas, ya en torno a la mitad del siglo $\mathrm{V}$ a. C., se inquietara por los riesgos éticos y los efectos colaterales políticos del nuevo negocio-paideia sofista es algo que puede deducirse entre otras cosas de las producciones del teatro ateniense. (Sloterdijk, 2015:180)

Que la estructura visible que constituye una escena, esté montada sobre la parcialidad indirecta de frases-sentencia, y se mantenga como sístole de vida y rima de un pensamiento que mejor se resguarda en su backstage, merece ser entendida como una contumaz declaración de principios. Que una forma oblicua en la escritura, retórica, como es cambiar el orden de las componentes lógicas de su estructura para amplificar por la forma lo que el sentido sólo enuncia, sea la que poetice y ponga en representación la evidencia del fin de una era (como suma de apariencias y de encarar temerariamente un desafío), merece ser objeto de satisfacción de nuestra curiosidad.

En un sentido impositivo, de creación original, de obligación de cumplimiento, de exigencia de castigo, toda oración que se inicia con un que (su quid), que se repite a lo largo del texto, se muestra como la cadencia de una con- 
dena que se cuenta por las horas irremisiblemente golpeantes anhelando su final, o por la soberbia de quien se sabe en la posición irónica, sardónica e indolente de generar las retóricas más sublimes para conformar su argumento.

Sólo quienes tienen esa potestad, sean dioses o filósofos, representan a los ojos de los demás la conformación de una teatralización donde los actos, ensayos, libretos, críticas, intercambian posiciones. Teatro, Theatrum Mundi, será lo que nos explique nuestro mundo -en la escombrera ${ }^{1}{ }^{-}$, cuando el poeta divino o el poeta amante de la sabiduría (en esta categoría caben los arquitectos desde que Dinócrates leyera a Vitrubio) anuncien el fin de la Edad Moderna, esta vez sentados no sin cierto recelo en la platea. La trama es trágica, no hay duda, el fin de algo que nos ha hecho ser lo que somos, pero en el tono irónico (eironeia) del quid de la cuestión del actor vestido de calle, se prolonga la vida transitoriamente, lo cual nos permite verla fuera de nosotros mismos, y como tragicomedia.

No es nuevo tal que-hacer. Desplegar el panorama, la visión del estado de la cuestión, jugando a problematizar la relación entre la ficción y la realidad se denomina metaficción y acusa ser un estilema de la postmodernidad. Reposicionar al autor a las bambalinas y al espectador a que sea el punto de referencia (deixis) de la obra, por su presencia inserta, disgustaría sobremanera a Harold Bloom. Para el teórico literario neoyorquino, que Foucault descabalgara al autor de su silla y hasta de su peana, dejando el caballo arriba, dejó sin solución qué hacer a partir de ese momento crítico. No obstante, el recurso de la retórica es insoslayable para él: $s i$ se busca una verdad que desafíe la retórica, quizá habría que ponerse a estudiar economía política o análisis de sistemas y abandonar a Shakespeare a los estetas y al público de gallinero, que se aliaron para elevarle al primer lugar (Bloom, 2009:70).

Recordar a Bloom y su concepto crítico de la angustia de las influencias demanda una doble atención. Por un lado, Bloom insiste en la pertinaz condición de la literatura por concentrarse en su autonomía, y su explicación (mordaz y desafiante) aterriza como el vuelo de una hoja de papel, dando golpes de cintura de mayor amplitud angular conforme va bajando a las capas más bajas de los instintos de sus adversarios. Quien entiende que el ser que es uno se forma por los unos que son ser antes que él, entiende a Bloom, minusvalora el sentido de la autenticidad u originalidad, y promueve un cierto sentido de imaginario colectivo. Para aquellos que condicionan morfologías y creodos en el aparecer de su ser reserva Bloom el término canon. Canon no es la falacia de un conservadurismo tipológico ni su destrucción el adalid de renovaciones sociales. Tan sólo nos sirve $^{2}$ para concentrar nuestra puesta en escena en la recurrencia de que pensar lo que vemos no es justo su tiempo ni la trama, sino los tiempos y tramas que navegan como experiencia histórica del colectivo, por encima de sus vidas e indistintamente más allá que hacia delante o atrás en el tiempo.

Ese más allá es el prefijo meta, que junto a teatro, metateatro, es un sentido ficcional, autorreferencial, y explica en su puesta en escena, el mundo. Más allá y con las posiciones cambiadas (meta y anáfora), se trata de un teatro que emplea la anáfora conceptual (que se define como la repetición de la palabra inicial de cada frase, y en nuestro argumento es que, pero también es la anáfora el uso de una expresión que sólo alcanza sentido por otra ex- 
presión inserta en el contexto) como particular metáfora gramatical.

El otro lado de la autonomía es la vida como sueño. Bloom trató de hacer una lectura de Freud a través de Shakespeare, como para dar una oportunidad al gran cerebro del siglo XX, toda vez que no es concebible que el autor de la interpretación de los sueños cayera en su propia añagaza atribuyendo autorías diversas al autor del Hamlet. El historiador Carlo Ginzburg (1999: 157) se hizo cargo del deber retirar el pase permanente del que gozaba el psiquiatra vienés en la representación del mundo. En paralelo a la desactivación de las teorías de Jung del inconsciente colectivo, el ataque a Freud se basa en el crédito concedido a la herencia psicológica y cultural que reciben los hijos de los padres, exacerbada cuando creemos que existe una predisposición a ir más allá (meta) reviviendo el individuo no lo que su generación recibe de la anterior con la que convive, sino el influjo de una corriente que proviene desde incluso la prehistoria.

Quizá la tranquilidad y ligereza con la que se trata aquí la cuestión del sueño pueda meramente ser (mal) entendida por el juego de canjes que concede vernos insertos en una representación escénica de la realidad y no en la supuesta realidad misma. Así hemos enunciado y desarrollado in-formadamente este escrito-obra teatral, donde el problema de lo que pueda ser lo real es asunto de primer interés ${ }^{3}$. Sin embargo, no es un asunto casual o digresivo (¡hablar, hablar mientras se pueda, eso es todo!, denunció Aristófanes ${ }^{4}$ ) esto del sueño y el despertar, como dialéctica, como conciencia, de clase, de voluntad de resistencia a un imaginario sobreimpuesto, etc.

En La guerra de los sueños, Marc Augé evalúa el dilema de encontrarse entre dos mundos. Sean realidades o sus representaciones, sean los mitos o la angustia ante un futuro incierto, anticiparse al fin del proceso de Modernización, lo que Sloterdijk llama reiteradamente el principio dinámico-civilizatorio, reclama la presencia de profetas, visionarios o rebeldes que, como casus belli, alimenta sus sueños con la imagen que lo fascina y a través del sueño busca una nueva revelación (Augé, 1998: 102). Naturalmente, el antropólogo francés no sospecha que en ese capítulo esté él hablando del tránsito entre Edades (lo que sí es evidente en el último de los compendios del libro) ni en su vertiente arquitectónica. Pero cómo no ver como profeta a un Koolhaas (Sendas oníricas de Singapur: retrato de una metrópolis potemkin ... o treinta años de tabla rasa), como vidente a un Schumacher (Fluid Totality - The dream of inhabiting a nature-like built environment), o como rebelde a un Santiago Cirugeda ( $€$ spanish Dr€am), por poner casos cuya capacidad de contagio onirocrítico es de grado epidémico. Antonin Artaud, en El teatro y su doble (2001), constata la condición de la realidad como la verdad que emana de la epidemia, de peste, anunciada premonitoriamente por un sueño donde un cuerpo infectado sin signos externos de afecciones es análogo al del actor, penetrado por sentimientos desasidos de su yo: todo reacciona hasta el paroxismo, dice Artaud, pero nada ha ocurrido. Tal exceso, de felicidad teatral, se debe rastrear hasta el encuentro de su origen, en tanto que tal lejanía mejora lo certero de su implicación en el presente.

Tal vez con el Decamerón, pueda decirse que se interrumpe la historia natural de las cosas, en la que todo lo que ocurre queda abocado a lo mismo, como asimismo ocurrió con la historia que nos juntaba como humanos con Dios, que vino después. Bocaccio inaugura una 
serie de cancelaciones insertas en el proceso de modernización que culminan con la apuesta no muy bien aún asumida, desde hace más o menos 4 décadas, que pretende incluir la historia natural en la historia humana, que llamamos ecología aunque la pensemos como desarrollo sostenible. La primera de esas inhabilitaciones proviene del entendimiento de que el Renacimiento es una embestida a la resignación ante el infortunio, que dominaba a los humanos hasta el momento en que se puso fin a la Edad Media por la sanación contracultural de un principio de esperanza cuyo leitmotiv rezaba de nuevo con labios móviles ${ }^{5}$ como una voluntad de cultura, un informar anticipadamente moderno.

Los trabajos de Le Goff (2015) sobre la civilización del Occidente Medieval y la fundamentación social del sueño individual y colectivo son puntos de apoyo sólido para nuestras intenciones de reconducir las actuales tensiones psico-dinámicas por la sensación de cercanía de las fechas de caducidad de una época mientras convive con los indicios de otra, que por demás no trae mode d'emploi. Las dos caras del dios Jano, dios de inicios y finales, se miran a los ojos, somnolientos, quizá incluso sonámbulos.

Le Goff arguye que lejos en el tiempo, desde los albores del primer milenio y hasta el siglo XVII, las narraciones de los sueños (tenidos en estado de vigilia) podrían ser consideradas como contrasistema cultural. Hoy, como entonces, el sueño subversivo es objeto de atención. Sueños individuales pueden conectarse entre sí y ello evoca la trascendencia que alcanza una comunidad cuando se reconoce como tal. Pero también es objeto de deseo de control, mediante tecnologías electrónicas, informacionales, publicitarias y de consumo o, de otro modo dichas: las tecnologías al servi- cio del capitalismo de ficción. Baste recordar la frase I have a dream para que emerjan cientos de miles de dreamers tratando de alcanzar ese sueño, empezando por reclamar su derecho a nacionalidad, igualdad y voto. Más adelante insistiremos en esta cuestión del wish-fulfillment.

Augé mantiene como hipótesis que en toda creación, sea individual o colectiva, que se superponga a otra o que se agote como fuente de generación de imaginarios, puede perjudicar al simbolismo y memoria colectivos. Que existe una guerra de los sueños, para hacerse con el control de lo que Freud formula amplificadamente como sueños seculares de la joven humanidad, no parece ser sino el motivo de este entremés de escenas finales, de enjuiciamiento final de una época. Jung lo retoma influido por el romanticismo alemán, donde la profundidad del sueño alcanza con él lo insondable del individuo y más allá (meta), la universal naturaleza ya despersonalizada e indiferenciada. Cómo no advertir de aquí derivado el influjo en los prolíficos trabajos sobre el sueño en Bachelard que tanto ha influido en los arquitectos y en la monumental obra de Sloterdijk.

Se ha de recordar aquí, una vez más, la moderna antimodernidad de las imágenes del deseo de Walter Benjamin con las que la masa procura doblegar y obtener para sí una alternativa transfigurada a lo que recibe como producto social. Tales imágenes del deseo regresan, tanto para Benjamin como para Freud a un pasado primitivo pre-histórico, sin clases, y vuelven como generadoras de profecías. Para otros fines, la tectonicidad en la representación de la arquitectura en el tránsito del XIX al XX, ha descrito profusamente este argumento el desaparecido Detlef Mertins en su Benjamin's unconscious ${ }^{6}$. 
Hemos elegido una imagen para esta escena inicial. Se trata del primer daguerrotipo dado por bueno -otros incipientes intentos de químicas fallidas se conservan también-' donde aparece una figura humana. Es una vista desde el tejado donde tenían el laboratorio y el Diorama Daguerre y su ayudante Hubert ${ }^{7}$. Esta imagen es famosa por varias razones, entre otras, ser considerada la primera, y por verse una primera figura humana. La importancia es captada por Agamben ${ }^{8}$, que en su libro Profanaciones (pág 30), hace confusión entre ese ser y la humanidad entera.

Al dejarse ver, ese hombre sobreexpuesto (el procedimiento daguerriano empleaba entre 10 y 60 minutos de apertura de foco), enjuicia lo que somos, nuestra existencia, por el más vano gesto banal de la quietud del que se deja lustrar unas botas. Todos los demás seres se han borrado ${ }^{9}$ y ni el bullicio de la calle -la calle que fue luego desmontada, destruida, recompuesta por la perspectiva haussmanniana ${ }^{10}$-' impregnó la placa.

A nosotros lo que nos impresiona de esa fotografía es su carácter ficcional, no sólo por ser una calle donde abundaban los teatros (ver la Guía Galignani del Nuevo París de 1862) o por la estaticidad que sobrevive al cambio, sino por su virtualidad, entendida ésta como las miles de cosas que quedan adheridas, flotando en el espacio profundísimo de la superficie de inscripción ${ }^{11}$ de la placa.

Como una representación de todos los instantes del batir de alas de una mariposa -'así define Pessoa las sensaciones de las cosas mínimas-', esta imagen de la Rue du Temple del verano de 1838 sobreexcita los tiempos de la experiencia, acumulada y reposicionada en lo que llamamos ciudad. Daguerre no estaba inte- resado en obtener un principio de fidelidad a lo real, sino alcanzar a presentar desproporcionadamente los pequeños detalles de las sensaciones, el deseo y lo fantasmagórico, que de seguro Pessoa $^{12}$ conocía, al juzgarse a sí mismo (a su sí mismo sin su raciocinio y afectos, su Bernado Soares) como una placa fácilmente impresionable (Pessoa, 2013: 73).

Ardo en deseos de ver tus experimentos tomados de la naturaleza escribió Daguerre en 1828 a J. Nicéphore Niépce, una emocionada frase que dio pie a la investigación de 2004 de Geoffrey Batchen sobre la fotografía, donde puede obtenerse una concisa consideración del pretexto fotográfico: el objeto fotográfico no es por sí mismo, sino por el campo asociado por un sujeto unitario, que no es el superviviente sobreexpuesto que se ve en la imagen de Daguerre, sino que el que toma la imagen -Daguerre mismo-' es quien provee una relación imaginaria y geométrica de ese sujeto con el espacio real.

Es decir Batchen, apoyado en tres autores (Sekula, Burgin y Tagg) problematiza sobre la base de que toda fotografía carece de objetualidad, de identidad per se y su historia está desposeída de unidad. Tales características son constitución de una base formalista del hecho fotográfico que para Batchen (2004: 201) y para nosotros apoyados en él, atravesados los rápidos que amenazan la estabilidad de esos rasgos, se disuelven sobre los pigmentos de cada toma que se acerca a nuestra época. Contravenir lo formalista será participar de las inversiones que la relación entre naturaleza y cultura exhibe, exacerbando el polo cultural y alimentando un reconocimiento de la caída en lo postmoderno.

La postmodernidad en la discusión sobre la fotografía recurre a la crítica a la ideo- 
logía, a la cuestión del poder, a la separación realidad/representación, primando ante cualquier otra posibilidad, la representación ${ }^{13}$. Sin embargo, puede decirse que lo que nos interesa señalar no son tanto estas diatribas sino la evolución de la percepción que por qué no asumirlo, cambia en virtud de las transformaciones de los discursos de la visión. La fotografía de Daguerre, al juzgarse a sí mismo, como Pessoa, cambiando lo visible que muestra, por lo visivo del sujeto tras el aparato de captura es una catalización de deseos invertidos en la mirada.
Es este aspecto, que se enmarca en lo formalista pero que se enreda en las reflexiones de Lacan sobre el imaginario ${ }^{14}$, será la clave de nuestros supuestos, generando nosotros una serie de escenas de deseos invertidos en la mirada, como que fuera el tiempo quien mirara hacia la cámara y se preguntara cuáles serían las significaciones imaginarias para una sociedad considerada (en nosotros, occidental), pues ciertamente, en realidad, son el mundo.
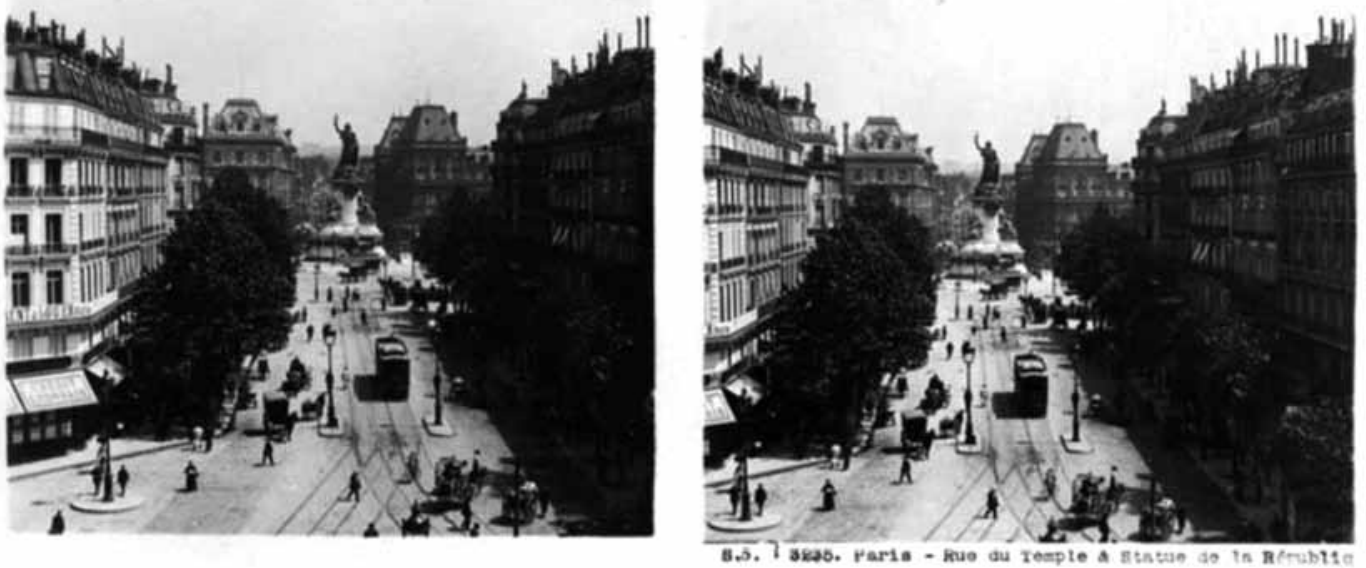

Fig. 2 Imagen Estereográfica del Boulevard du Temple (cerca de 1900). 


\section{ACTO 2. LA CIUDAD CON-SIDERADA UN INTERIOR.}

\section{Paysage}

Je veux, pour composer chastement mes églogues, Coucher auprès du ciel, comme les astrologues, $E t$, voisin des clochers, écouter en revant Leurs hymnes solennels emportés par le vent. Les deux mains au menton, du haut de ma mansarde, Je verrai l'atelier qui chante et qui bavarde; Les tuyaux, les clochers, ces mâts de la cité, Et les grands ciels qui font rêver d'éternité.

\section{(Charles Baudelaire, Tableaux Parisiens, Fleurs du Mal). ${ }^{15}$}

Gershom Scholem conservaba la única copia de un texto de su amigo Walter Benjamin en el que se habla de la cercanía y la lejanía (Gesammelte Schriften II, 1411). Benjamin dictamina que el hombre no actúa en vista de lo que está por venir, como si se pudiera determinar su trayectoria, sino con vista, sabiendo que lo que se acerca viene de lejos. Así, consultar los astros resulta ser más profundo y adecuado que reflexionar sobre lo inmediato de tal forma que no necesariamente lo que llega viene del pasado y conduce a un futuro. Allí, en los cielos, pasado y presente adquieren una realidad compuesta, dado que la luz concierta los diversos tiempos cohabitantes. De la misma manera, mirar a los cielos no implica alcanzar conocimiento para el rasgo menor que constituyen los actos vitales, sino para la amplitud de la propia vida, única, y que puede tener destino.

De acuerdo con David Harvey en su libro sobre París, Baudelaire se debatía en el inicio de su producción literaria entre la adopción y la repulsa de las formas naturalistas de su época, las novelas de Balzac y Zola entre las más des- tacadas, donde el destino se manifiesta a través de un inflexible y materialista determinismo biológico, económico y social ${ }^{16}$. Benjamin, como Baudelaire -a quien el crítico Sainte-Beuve colocó en lo que él definió como la avanzadilla del Extremo Oriente-', finalmente se decanta y rompe con la idea de lo moderno como racionalidad estricta, a través de reconocer un canon que aclara lo oscuro que resulta ser lo que no es racional: el lenguaje. En él, en lo que se constituye como un dispositivo de virtualización de los tiempos, se desvelan los caracteres inconscientes del escritor.

Aunque no sintamos melancolía, como la sintieron Durero, Starobinski, Panofsky, Saxl o el mismo Baudelarie de los encuadres parisinos, la escena que vamos a proponer como objeto de este acto, admite prestar atención con las manos apoyando el mentón ${ }^{17}$. Nos permite saber anticipadamente que hemos de mirar con vista paciente una temporalidad que no es causal por ningún procedimiento histórico. Resulta ser tan ardua la empresa, que el verdadero observador (Benjamin lo llama historiador en sus Tesis sobre la Filosofía de la Historia) captura la constelación en que su propia época se hace visible, indisolublemente asociada con tiempos anteriores enteramente determinados.

Constelación es, en la terminología enrevesada de Benjamin, explosión ${ }^{18}$, salto y origen -'spreng, Sprung, Ursprung-' (Cuesta Abad, 2004:57), un tiempo-ahora que quiebra la historia como continuo. El pasado se retiene como imagen fulgurante que centellea para ser guía de una época en su legibilidad, a la que sólo a ella se adecua mediante su carácter de constelación. La imagen leída entre lo que ha sido y su ahora es dialéctica, ya no depende del tiempo (Benjamin, $\mathrm{AP}, \mathrm{N} 3, \mathrm{r}$ ) sino que es de naturaleza imaginal. 
Esto es el Proyecto de los Pasajes de Benjamin. Sobre ese inmenso trabajo conectivo con los despojos de la vida, se ha investigado y dicho una enormidad semejante. Y ha servido para reflexionar en la acción inconsciente colectiva y en la conciencia activada de la individuación. Al mismo tiempo, ha permitido diagnosticar, a través de las perspectivas de la cultura material y claves de pensamiento absolutamente reveladoras, la ciudad: la ciudad moderna, la ciudad contemporánea.

Con-siderar la ciudad contemporánea, establecer el vínculo de lo sujeto a tierra por el amparo de un cielo común, dado que considerar significa atender a la posición de los cuerpos celestes y su ángulo de referencia con nuestra posición, sería pensar en una textualidad paraláctica homóloga para la ciudad. Tal capacidad de legibilidad urbana tendría sus raíces en esa confianza marxista en la historia que profesa leer en las situaciones como otros lo hacen en los textos (Finkielkraut/Sloterdijk, 2008:13). Ello demanda creer que aún en su extinción, la luz de muchos astros continúa alumbrando nuestro cielo y que el arte de generar figuras con esos tiempos, cuerpos y posiciones relativas se denominaría contemporaneidad.

No será nuestra intención zanjar la demanda que hace Harvey (2008:27) sobre las teorías de la ciudad, que denuncia que son muchas en la ciudad, pero no existe la teoría de la ciudad. No parece sensato alcanzar un sentido de lo común citadino - marxista, como el geógrafo británico- donde mantengamos esa raigambre al modo de una figura de una superestructura para la ciudad. Por recordar meramente su significado, la superestructura, referida en el Prefacio a la Introducción a la crítica de la economía política por Marx, son con- formaciones culturales que se derrumban en el proceso de evolución del Mundo en su complejidad y sólo cuando se desmoronan, como consecuencia de cambios en la base, se hacen visibles tales superestructuras. Sin embargo, la cuestión por la realidad, que es lo que fundamentalmente caracteriza esta distinción, acaba adquiriendo la rigidez de lo estático, de lo estructurado, muy alejada de lo que podemos comprender hoy por realidad, dinámica en el sentido de Heráclito, siempre en movimiento, multilateral o dicho por Benjamin, dialéctica. Para el Diamat (abreviatura de la expresión acuñada por Plejanov, el Materialismo Dialéctico) la base acababa siendo materia, y la superestructura, espíritu (Ferrater Mora, 2009: 410). Y con espíritu incluimos la Religión, el Arte, el Derecho o la Filosofía. En la contemporaneidad, el reduccionismo que supone la separación entre raíces, tronco y ramas se ha superado con el rizoma de Deleuze, por poner una clara derivada y prevalencia, hoy ya igualmente sometida a enjuiciamiento. Aún en ese revisionismo de la llamada French Theory y de la sospecha nietzscheana, conforme a estas definiciones pero en términos arquitectónicos, una catedral no será expresión como superestructura de una sociedad feudal mientras su sistema morfodinámico funcione. Tan solo llegará a serlo cuando los sistemas simbólico-productivos sean otros y las propias catedrales sean las que impidan el desarrollo de esa sociedad, que sucumbirá evidenciando la diferenciación base/superestructura ${ }^{19}$ que le fue propia.

En contrapartida a la intención de acometer una metateoría de la ciudad, y tratando al mismo tiempo de no particularizar por sobredeterminación de adjetivos para generar un procedimiento de focalización descriptivo 
(Cinematic City, Self-Portrayed City, Global Networked City, Postmetropoli, Post Political City, Provisional City, Splintering Urbanism, etc.) que depende del collage que habría que montar con todos ellos para sintetizar la escena de la ciudad actual, nuestro propósito es aplicar el modus operandi de Benjamin a la cuestión urbana. Tal cuestión, que fue ideológica antes de Castells (Brenner, 2013) y cotidiana e inserta en los medios de comunicación tras su libro de 1970 The urban question, se presenta ahora interrogando lo urbano como sospechoso a la hora de ser un marco factible o certero para una teoría radical ${ }^{20}$.

En síntesis, la exploración que aquí pretendemos mostrar trata de aspirar a la superación de la mirada benjaminiana en lo concerniente a la memoria melancólica ${ }^{21}$, pero con vista, es decir, gracias a la óptica que alcanzaron sus absorbentes Pasajes hacia la masa -y viceversa- para comprender la realidad como una heterogénesis de lo humano. Se supera, por tanto, la reducción que supone la polaridad base/ superestructura. Queden así vinculadas las nociones de ciudad y virtualidad, que se abrazan en un proceso de lo visivo (en lo cercano y lo lejano) que se abriría para nosotros desde el año 1709 con Berkeley ${ }^{22}$ y su nueva teoría de la visión, siendo el otro extremo temporal un debate abierto en la contemporaneidad. El intento benjaminiano, como el de Ernst Bloch, una interpretación desde el marxismo de un mesianismo al que fue iniciado por Scholem, deposita en el cine el aura necesaria para el sueño utópico de transformación social. Ya no se trataría del sueño individual freudiano (de los dominantes o de sus esposas, diría Sloterdijk) sino sueños de masas donde los anhelos del proletariado deberían mutar en acciones políticas.
En el debate del proceso de modernización, nada se muestra más alejado de Berkeley (Crary, 2008:87) que el dispositivo perceptual decimonónico por excelencia: el estereoscopio. La consecución del campo de profundidad ${ }^{23}$ espacial, su relieve, era mucho más que un efecto para el regocijo en el engaño al cerebro-ojo. Ya Baudelaire señaló en El pintor de la vida Moderna que tal aparato reorganiza la posición del observador, pero también las relaciones de saber y de poder. De este modo, la imagen de París para los medios de comunicación se constituyó en la década de 1860 en una fantasmagoría, un sueño, un espejismo, o una mascarada. Martin Jay (2007) relata la simbiosis de la habitual chanza de los procesos de transformación de la metrópolis, imbricados ahora en ironizar sobre su falsedad visual. Desde este momento, toda una maquinaria para el disfrute visual está aparejada a la ciudad, París, y desde ella todas las que asumen su sueño, con Nueva York como la mayor ciudad-estereoscopio a desear, de reduplicación de una realidad cuestionable, pero fascinante ${ }^{24}$. Será Jean-Louis Déotte quien mejor transfiera la posición excéntrica de Benjamin insertando el concepto de superficie de reproducción, esto es, que siempre ha de pensarse en virtud de un aparato que hace época, aunque en forma diferida, retardada. Ello obliga a hurgar en el pasado, para evidenciar nuestra contemporaneidad, porosa y constelada, como hace el trapero Benjamin en su tiempo. La casa del sueño colectivo, como el museo, que se han traducido como construcciones oníricas en múltiples ocasiones, presenta en Benjamin una paradoja de reversos, de desdoblamientos de modos opuestos. La arquitectura, que es exterior y envolvente para el individuo, si se traslada a un interior, como un pasaje parisino o el metro 
de Moscú, se convierte en una repetición de sí mismo eternal ${ }^{25}$, que se hace historia, política, memoria. Para el colectivo, por el contrario, son las casas del sueño las que están en un interior, en una experiencia fisiológica de envolvente singular, en la misma medida que el cine.

Por tales razones, Déotte (2012:87) concluye que es de crucial importancia el reposicionamiento de los intervinientes en la escena, de forma que el aparato que sirva para caracterizar una época no es el foco de la explicación que se requiere, sino para constituir una arquitectura de interior. Para ello se precisa de una tercera fase de la interpretación de los sueños, más allá (meta) de las de Freud y de Benjamin. Ambos autores están imbricados en la declarativa que hace Buck-Morss (2004:88) en Mundo soñado y Catástrofe en la profecía que muestra el proceso de derrumbamiento de una era. Si ella se cumple, y no hemos encontrado motivos para no aceptarla, sucede que la Historia se muestra descompuesta por imágenes y no por relatos.

Imágenes que más bien son sueños emancipados de todo espacio-tiempo, engarzadas en redes de memoria y de pasados redimidos. Tales imágenes, como las que encabezan cada una de nuestras escenas, sólo admiten interpretaciones parciales en su fragmentación, pero resultan liberadas de su narrativa sobreimpuesta y las deja en disposición de un mejor encaje constelado en el presente. Se trataría de sorprender, como el teatro de la crueldad de Artaud, más que de explicar. Sloterdijk (2007:74 y 86) aclara el procedimiento deconstructivo aplicable: mínimos gestos a inocular como fermento en la textualidad ideológica mezclada con su deriva onírica interior, a sabiendas de su inevitable fracaso. Fracaso porque ya no hay intérpretes gramatológicos de sueños, ni son necesarios.
Más bien, se requeriría desde la oficina onirocrítica de empleo, a cualificados curators que organicen los espacios para los archivos a ser expuestos worldwide. Así se gesta la operación del comisario de los sueños Boris Groys, de quien Sloterdijk (2007:88) sigue diciendo que la diferencia entre Derrida y Groys se percibe por una diferencia edilicia. En el primero, su edificio destinado a archivo es de paredes fluidas o mejor, sin muros, habitado por residentes tan heterogéneos como para que la envolvente faltante se supla por las derivas infinitas movedizas. Para Groys, en cambio, el edificio es un museo. No el de Barthes, diríamos nosotros, sino quizá más cercano a una smart upgrade del Mundaneum de Le Corbusier: de nuevo, constituir un interior de exteriores.

A pesar de la diferenciación, no reconocemos en ambas sino una formulación alotópica ${ }^{26}$ de nuestro tiempo que se inicia con la profusión de uso del estereoscopio. Crary (2008:158) recoge el pensar de Baudelaire, que advierte de las consecuencias de acercarse el aparato, donde la visión binocular establece dos visiones diferenciadas en una, donde no hay identidades sino una experiencia de reconciliación de imágenes disyuntivas, cuyas vecindades no están vinculadas, al modo en que Deleuze hablaba de los espacios de Riemann. El estereoscopio, por estas razones, demuele la relación observador-escena de la estructura, el punto de vista, aún teatral, de la cámara oscura. Lo que se muestra al observador es la reanimación técnica de un mundo ya reproducido y descompuesto en dos modelos no idénticos, modelos apriorísticos que predeterminan la percepción inmediatamente posterior. En lo que a la ciudad respecta, la imagen elegida para este acto segundo es el de una estereoscopia del Boulevard du Temple, ya hausmannizado, con 
suficientes aportes interpretativos dados para alejarse del rostro el dispositivo, pero aclarando que no es por precaución contra el estrabismo, sino por insuficiencia de fantasmagoría, por una adicción a la hypnerotomachia ${ }^{27}$ nunca saciable.

El aparato caduco ya en el final del XIX provee una definición de nuestro tiempo en su obsolescencia, la ciudad como montaje dinámico de heterogeneidades, como la analogía de la catedral en el ejemplo de Marx. Arriba, en la de París, observa una gárgola, con sus manos en el mentón, ese diablo alado cojuelo, melancólico de tiempos en los que su maldad dictaba el comportamiento de los hombres. Analogías: correspondencias de relación especulativa (espejo de sí) y de eje vertical (de simetría).

Odilon Redon ilustró con un daímon alado el libro Les Fleurs du Mal de 1890, dado que para Baudelaire, asomarse a la vertical mirada desde el balcón significaba tristeza y melancolía ${ }^{28}$, que compensaba cerrando ventanas, encerrado en su monadológico interior.

\section{ACTO 3. LA CIUDAD VIRTUAL COMO ESCENA.}

La estrella de la catedral se está acercando girando por sí misma, bailando

bailando, cambiando de forma y brillo

yendo y, de nuevo, por mucho tiempo, al espacio azul oscuro música en fórmula etérea

hojas verdes flotando arriba, y desde los lados de abajo / lel orbe aparece, resale

internamente cubierto de un verde brillante...

(Narración en off, del alemán nuestra traduccción, minutos 8'30" a 11', "Der Weltbaumeister" Bruno Taut.

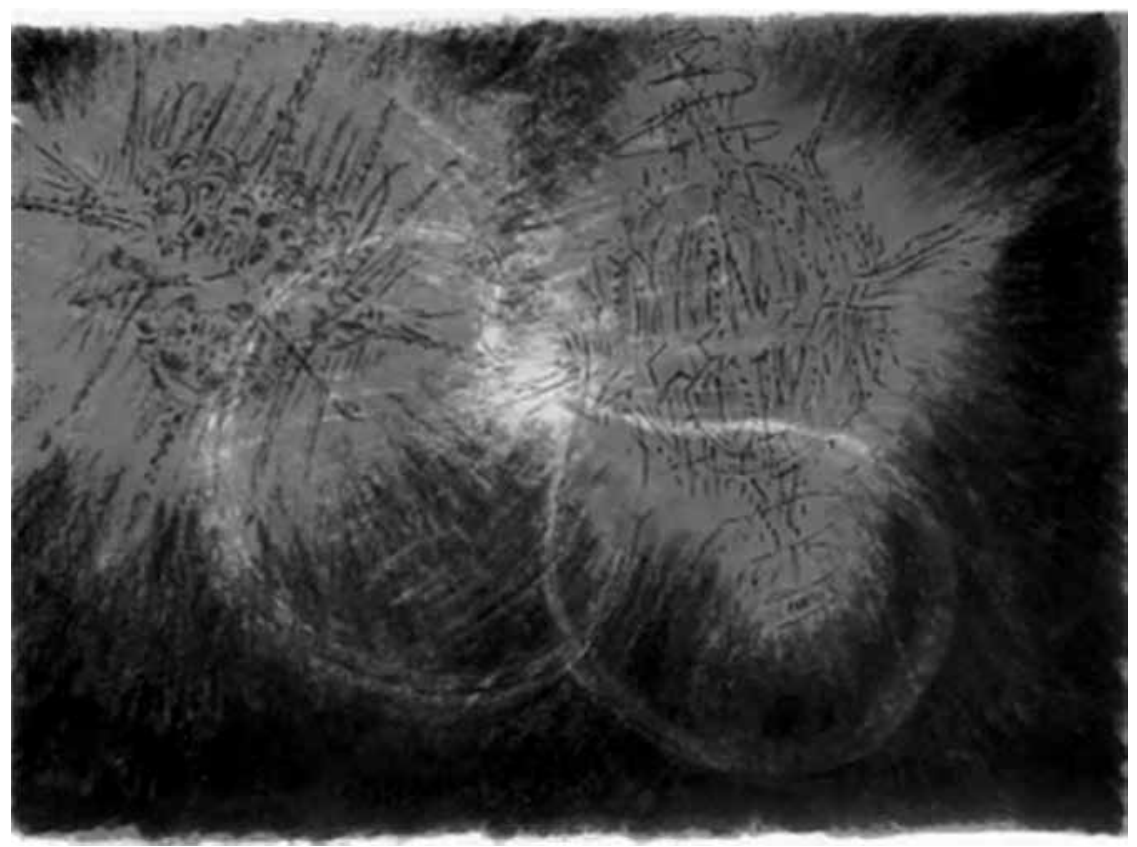

Fig. 3 Fotograma del film de Bruno Taut de 1919 "Der Weltbaumeister/Architektur-Schauspiel für symphonische Musik". 
Se dice que quien no haya leído el libreto de una representación operística sólo acude a ella entregado a una sub-impresión estética, casi vacía de contenido lírico, no sólo por la dificultad de entender lo que los cantantes dictan, aun en el raro caso de que se domine el idioma escuchado y su retórica, sino por lo distante del tema en su composición, que además, se rinde a la potencia de la imagen -y música es imagen desde Bayreuth.

Quien menta el teatro wagneriano exige una consideración similar a no dejarse entregar al placer estético inconmensurable de la exaltación musical -la existencia del mundo sólo se puede justificar como fenómeno estético- sin haber pasado por las arcas nietzscheanas.

Arcas que son para dejar tributo pero también de las que llevarse el suplemento vital que se halla en ese conocer previo, extendido. No se hace mención sin que haya al mismo tiempo un hablar de qué conocimiento se ha de emplear para la obtención del aditamento. Coincidente con el Nietzsche que pone en jaque teoría y práctica y el origen de la modernidad hasta ese momento descrita -el del origen de la tragedia griega- Sloterdijk empujará la figura (chess piece) del autor del Zaratustra hasta sacarla del tablero y configurarle una escena, la del pensador on stage, cuya posición excéntrica encuentra concurrente con el entendimiento de la supuesta superación epocal que llamamos postmodernidad.

Contrariamente a Lyotard, para Sloterdijk habría que dudar de que nuestro tiempo se caracterice por narratividades, y propone en su lugar escenificaciones más cercanas a la teatralidad de la commedia dell'arte, cuyo relatar es responsabilidad de la capacidad de improvisación de los comprometidos actores en el paso de una escena a la siguiente. Cada actor se sobreexpone -riesgo y permanencia-, pero no sobreactúa, puesto que su presencia es su ausencia, en tanto que lo que se representa es el momento del mundo interpretado por él (Sloterdijk, 2000:56).

Sólo así puede entenderse un libro de filosofía como el de Michel Onfray (El sueño de Eichmann, 2009), donde sacado del encuadre, Onfray coloca en su lugar al nazi Eichmann durmiendo la noche previa a su ejecución sumaria, en su celda en el escenario, con imágenes de Hitler proyectadas atrás, como un segundo bastidor de fondo y en foco paralelo, Nietzsche en una tumbona.

Se sabe que es él por el inmenso bigote, ya que está envuelto en una tela hasta el mentón. Kant entra, y despierta al ejecutor de judíos para interrogarle por la lectura que éste hizo de aquél. Hanna Arendt está presente, en su ausencia. Ella había escrito que la autodefensa del que va a ser ajusticiado, apoyada por leer a Kant, era insostenible: no lo había entendido. Sin embargo, Onfray sí encuentra ese totalitarismo en Kant, que duda de sí mismo en el diálogo que se provoca. Se trata de partir del sueño, que ampara al crear y mantener en vigilia los más monstruosos paralogismos ${ }^{29}$. Así se funda la obra baudeleriana en su conjunto, pero con carácter particularmente arquitectónico ( $\mathrm{Ca}$ lasso, 2011:175) si consideramos el único sueño relatado por él, el de la visita a un burdel. Visiones, derivas en abîme, escenas eróticas, dibujos de arquitectura, dibujos egipcios, corredores imposibles, piranesianos, todo ello convive en imagen dialéctica, que desde Benjamin significa revelar una síntesis auténtica, notar el fenómeno originario de la historia (Urphänomen).

El ojo-Onfray es el usuario del limpiabotas visto desde el balcón -cerrado con crista- 
leras- de Daguerre, ambos ausentes para hacer presente el enjuiciamiento universal de la ciudad en los últimos días, por la mediadora desfiguración del sueño. Constelar dijimos, el libreto ha de leerse, dijimos: el ojo que mira a la cámara se reconoce si uno aprendió arquitectura.

Tafuri decidió un aperçu para La esfera y el laberinto hablando de los ojos de Borromini en Pesaro y Roma y las desfiguraciones de los espejos convexos, como clave de lectura previa a la lámina IX de las Carceri de Piranesi. Entstellung es el término clave freudiano que designa la desfiguración, en su doble acepción de alteración y desplazamiento. La lámina IX desplaza intencionalmente los ejes perspectivos circunscritos a una óptica del siglo XVI, de por sí teatral en el Barroco tardío, convirtiéndose así en una crítica sistemática al concepto de centro y coloca incómodamente al grabador de las imágenes en el encuadre, el plano elegido para la representación del espacio. La lámina IX proyecta más acá del ojo todo el aparataje estructural atravesando, dice Tafuri (1984:32), un segundo bastidor que alberga otro óvalo emergente desde la profundidad del espacio, que además, evidencia que no se trata de un exterior, sino de un interior que engulle al observador.

Tal apertura es preámbulo para el tercero de los capítulos del libro de Tafuri, donde la hipótesis se lleva al título: La escena como ciudad virtual. Piranesi es el personaje de Daguerre, en tanto que queda detenido en pos de un desplazamiento mayor que él mismo cuando el pensador Tafuri es llevado a escena. Es un apóstata, Piranesi, que arrastra al público al universo de la virtuosa locura.

Es cierto que Tafuri no olvida deshacerse de su título aunque lo mantiene. La analogía, esas correspondencias baudelarianas, se carga aquí cuando describiendo las escenografías de las vanguardias de inicios del XX (Poelzig, Meyerhold, Popova, Marinetti...) se reconoce en ellas una suerte de contra-ciudad, el negativo de la metrópoli. Tal contra-espacio no pasará a ser fenómeno originario de la historia nunca, puesto que la gran ciudad es ya, hasta nuestra época, teatro absoluto ${ }^{30}$. El título, por tanto, debería ser: la ciudad virtual como escena.

Lo virtual proviene de virtus, virtud que para Pierre Levy (1999:12) significa descubrir una problemática aplicable a una entidad cualquiera (su virtualización), hacerla mutar por una cuestión particular y redefinir la actualidad de partida. La realización sería la ocasión de concretar algo predefinido y su actualización consistiría en inventar una solución a un problema que se plantee. Por tanto, actualizar es lo inverso que virtualizar en tanto que se trata de un dinámico desplazamiento del centro, de su ontología, del objeto a considerar a partir de un campo problemático. Es una potencialización, en su permanente indeterminación.

La imagen elegida para nuestro acto tercero es un fotograma en transición de la película de Bruno Taut de 1919 constituido por el dibujo de Carl Krayl La Catedral radiante. La condición de tránsito virtual de analogías del sí mismo con todos los que son antes que él, como decíamos con antelación, se aclara con la frase que el escenógrafo Appia usa al preguntarse cómo la exteriorización cotidiana -limpiarse los zapatos- se funde con lo espiritual para generar el materialismo de lo incorpóreo, la escena, un interior: el hogar se vuelca a la calle y la vida al aire libre irrumpe en nuestras ventanas (Tafuri, 1984: 128).

Pero, ¿qué es una catedral ${ }^{31}$ Para Appia, imagen del porvenir, donde el arte dramáti- 
co florecerá con o sin espectadores. Tal renuncia obliga a todos a someterse a la escena, a las escenas dislocadas que deben llegar, de anticipar la posición de los ojos para los miles de zapatos que habrá que lustrar. Taut, queriendo atar la transformación total del universo no pudo finalmente realizar la versión fílmica de un cuento para calzar dos milenios. Tal cuento se llamó Die Galoschen des Glücks (Los zuecos de la suerte) y el guion imponía la necesidad de transiciones continuas en los cambios de escena. El cuento es una versión de Los zapatos rojos de H.C. Andersen. La trama cuenta las tribulaciones y desesperanza de un joven sin trabajo que se separa de una mujer mientras evoca su miserable pasado. Unos zapatos se ven en el camino y al calzárselos, todo lo que era desgracia es ahora felicidad, trasladado al año 2000, en el futuro. En una especie de vegetal hay algo equivalentemente enigmático como una casa, de la que sale un hombre que invita al joven a un aposento fantástico.

Con un bastón, el hombre comienza a crear tocando las puntas de las plantas, casas nuevas, construcciones en forma de alas de mariposa, articulando visiones oníricas y finalmente sueños profundos. Sin aclarar si se sale o no del sueño, se producen nuevos encuentros, la chica parece que vuelve o se le parece, un doble, se viaja al año 3000, se reinsertan hechos históricos conocidos con deseos cumplidos de transformación social, política. Distintas aventuras llevan a encontrar una zapatoteca (biblioteca de zapatos) numerados por años. Unos zuecos son recogidos de una de las innumerables estanterías: la humanidad está gozosa de ver cómo se sienten ellos al despertar.

Un interior que alberga casas, zapatos, sueños, dobles, alas de mariposa.

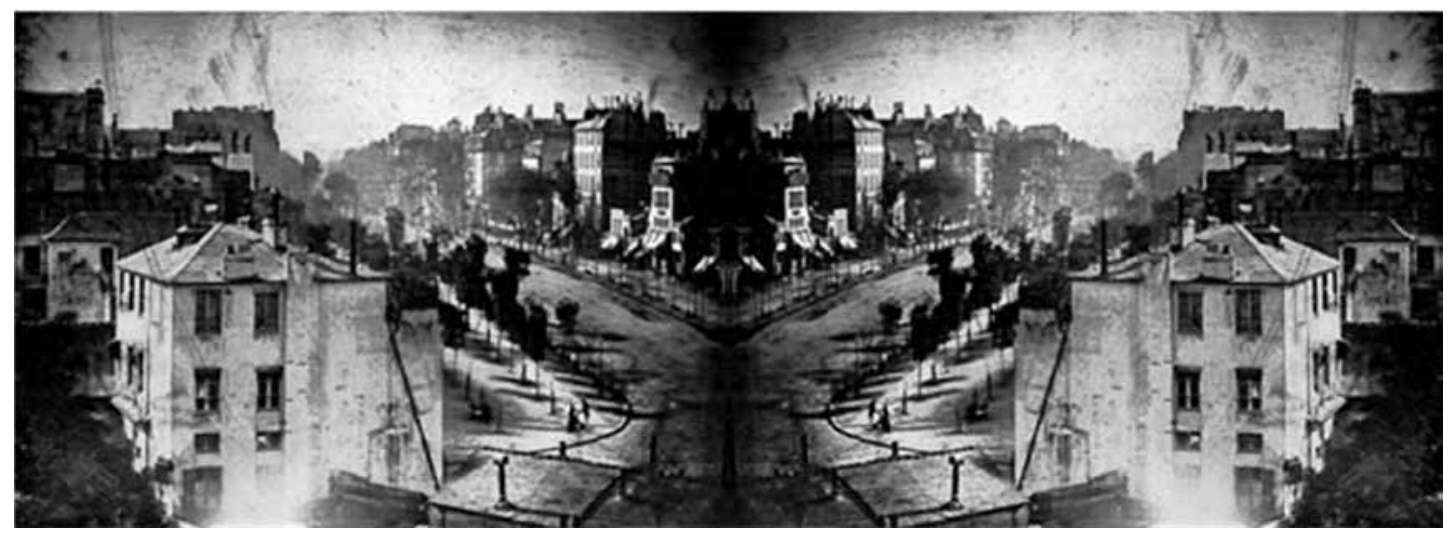

Fig. 4 Montaje del autor. Simetrías y antisimetrías. Boulevard du Temple. Imagen-Espejo. 


\section{ACTO 4. QUID TUM.Y, ENTONCES, ¿QUÉ?}

La peculiar indecisión del flaneur. Del mismo modo que aguardar es el estado propio del contemplativo inmóvil, parece que la duda lo es del flaneur. En una elegía de Schiller se dice: "Las alas indecisas de la mari(p)osa”. Se presenta en la misma relación de impulsividad y sentimiento de duda que caracteriza a la embriaguez de hachis.

(Konvolut M 4 a,1. El libro de los Pasajes. W. Benjamin)

Cuando el mundo moderno se hace verdaderamente moderno adopta la forma de un experimento de admisión de ambivalencias. Anoto sin cita esta frase precedente que no es de Sloterdijk (2015:19), porque reconozco en ella un aliento que no es de paternidad reconocida en su contexto sino como anáfora y repetición de sublimaciones temporales (Urphänomen). El filósofo-literato alemán no precisa comillas cuando la inmersión es tal que es suya la afirmación en pleno derecho del sentido uncanny ${ }^{32}$ del proceso de Modernización hasta nuestros días. Que no haya sino disoluciones, tiempos y hechos que van del sueño a la vigilia, de lo visible a lo invisible, requiere equipos técnicos cualificados que devuelvan la conciencia del orden de las cosas.

No que devuelvan el orden, sino una conciencia del orden, apariencia de canon, detener el instante en el que es posible entablar acuerdos relacionales. Zigmun Bauman (1996:73), que escribió en 1991 Modernity and Ambivalence (Beriain, 1996), aduce que podemos pensar la modernidad como una era que refleja en su interior el orden del mundo, del hábitat humano y de lo propio individual, junto con la interrelación consciente de esos tres factores en su dispersión. Añade que al hacerlo -datar, medir, comparar, entre otros métodos de laboratorio- pasa lo que a la mariposa que clavamos para su contemplación: no sobrevive. Cuando Daguerre sale a su balcón, dispone su aparato, abre el obturador, espera y saca la placa impresionada, lo que obtiene es una imagen espejo. No es una imagen invertida, sino de simetría lateral de eje vertical. ¿Qué podría suscitar componer una imagen y su doble? Respecto a acercar una realidad llegada a ser por su representación, que ya no depende sino de su infinita virtualización, en crisis por su espectacularización, en potencia por su explosión, convendría ampliar el Discurso Interrumpido que hacíamos de Benjamin respecto a la lejanía y la cercanía. Él se pregunta (1989:72) si la complacencia en el mundo de las imágenes no será una obstinación sombría contra el saber. Ver no es ver, dado que la misión en la contemplación del mundo, en su lejanía, no está en su reposo, sino en la excitación de cada acercamiento, donde el soñador pone coto a la Naturaleza en el marco de desvaídas imágenes y el poeta la conjura bajo una llamada nueva ${ }^{33}$.

De médicos también es concerniente la transformación exigida, si pensamos en el galeno de Hölderlin, Justinus Kerner (1786-1862), cuyas kleksografías, consistían en imágenes formadas sobre manchas de tinta, verdaderos poemas que las identificaban como nuncios del inframundo, adentradas en el nuestro como reversos por la fuerza invisible del magnetismo animal.

Kerner doblaba el papel con la mancha, obtenido una suerte de ente alado, con un cariz 
turbador, provocado por simetrías que marcan métricas por distancias entre ser y no serlo. Simetría, esto es, competitividad. Mirar a derecha e izquierda vela lo que desvela la relación, un lado u otro, un lado y otro, múltiples relaciones, un instante provee reconocer una constelación, el siguiente la desdibuja. Si no hay un objeto en común, describir las orientaciones, las relaciones paralácticas, a otro observador, se hace complicado en un supuesto de aislamiento espacial. Martin Gardner escribió un libro en 1964 titulado The Ambidextrous Universe: Mirror Asymmetry and Time-Reversed Worlds. Por su lectura, creemos reconocer algunos presupuestos implícitos de la tesis doctoral de Enric Miralles Cosas vistas a izquierda y a derecha (Sin Gafas) de 1987, donde el experimento de excitación por las imágenes re-encontradas, cumplían con los que-haceres de médicos, poetas o durmientes. Sería posible también echar mano del libro de familia de F. Ll. Wright, para que la queja contra la rectitud en el camino sea la felicidad cuando de deambular de derecha a izquierda fuera de los límites del espacio se trata.

Desde que Loïe Fuller en 1900 constituyera una escena- $p s y c h e^{35}$ radicalmente libre, que encandiló a Mallarmé, Rodin y Valéry, pero también a Tafuri, la cuestión sobre la prioridad de pensar el espacio desasido, cambiante, instantáneo y creado por los bastones bajo la ropa en forma de alas de mariposa, se ha tornado una pregunta permanente. Gardner (1990: 171) incluye un poema de Nabokov a propósito del espacio: El espacio es un enjambre en los ojos; $y$ el tiempo, un canto en los oídos. Si no se ha leído el libreto, bien estará quedarse con esta apócope de lo operístico, a pesar de todo, sintiendo profundísimamente el soplo de pánico (Didi-Huberman, (2007: 19) que sentía Nabokov, eminente entomólogo, en el umbral del renacimiento de la crisálida.

En tales contextos, con tales amparos circunstanciales, la imagen que proponemos para este acto 4 es un montaje, un remontaje de la ciudad y su anti-ciudad, la captura de realidades que entablan una dialéctica para pensar el espacio. Ivan Illich (1998:347) definió el espacio como una creación social que resulta de la complementariedad asimétrica que entraña cada cultura y que lo envuelve todo.

El movimiento entre los extremos de la primera fotografía de la historia con su reverso, gesta un momento permanentemente original, un interior donde colocar nuestro imaginario como consciencia de des-orden.

A la pregunta de Benjamin sobre la confabulación de las imágenes contra el saber, su propia respuesta: un acto de su suspensión (Stillstand), un umbral entre la inmovilidad y el movimiento ${ }^{36}$. O dicho de otra forma, por Didi-Huberman o por Agamben, es ver volar una mariposa, puesto que la larga historia de la ambivalencia entre hombres y ninfas equivale a la espinosa correlación entre los hombres y sus imágenes ${ }^{37}$.

¿Tiene una imagen Tafuri? Sí, se la concede Cacciari, a su muerte, remachando la elección que el autor de Sobre el Renacimiento hizo en vida (Rovira, 2006:215). Tal imagen es un ojo alado y flamígero, metáfora del conocimiento. De su significado se deriva el mostrar a lo que se aspira quien quiere saber críticamente. Le acompaña un lema que fue el de Alberti y antes que él, de Cicerón: Quid Tum.

Con todo lo dicho, y entonces qué? Cada artista se interroga a sí mismo en su soledad, cada arquitecto se encuentra con su reflejo, su doppelgänger, un límite que evidencia la debili- 
dad de la acción humana, su soledad, su caducidad implacable. Howard Roark sale a escena, al encuentro de Ayn Rand (con Alan Greenspan durmiendo en el apartamento de los autodenominados The Collective), Franciska y Hermann Henselmann al encuentro de Brigitte Reimann (con Slavo Zizek buscando paralajes y repitiendo and so on...), Serenus Wiesengrund con un ataque de risa reclama su espacio (con Luis Castro Nogueira y T.W. Adorno dialogando a la sombra de los cerezos en flor), Eupalinos entregando unas monedas compensatorias a la causa Dreyfus (mientras Monsieur Teste, ajeno, ordena compulsivamente cientos de cuadernos), Solness cayendo desde las alturas de Ibsen (con Foucault prologando Sueño y Existencia de Binswanger o a los sueños de San Antonio de Flaubert), Peter Ibbetson empujando a du Maurier a su mundo onírico completo (con Gary Cooper y Moritz von Schwind aguardando con impaciencia la noche, como todos y cada uno de los prerrafaelitas). Freud está, pero no sale, ya Ginzburg se encargó de que se moviera lo suficiente como para que no impresionara la placa. Nietzsche no está, pero sale, sigue durmiendo en su camastro, hablando en sueños.

La gaya ciencia consiste, se le oye decir a pesar de su bigote, finalmente, en ser artistas, prolongar la duración del sueño, hacerse sonámbulos de día, sanar de la inmovilidad mortificante, y alcanzar la felicidad tras un largo periodo de privación e impotencia. DidiHuberman (2010: 78) lo asume como si de una primavera se hablara, un tiempo de abril, caracterizado por la embriaguez de la curación, como la que Benjamin buscaba en el opio y el hachis.

Arquitectos, los citados y casi todos los demás, seres-mariposa, con lugar propio en alguno de los seminarios de Lacan, quizá el de la imagen-espejo, donde se habla del sueño de Zhuangzi ${ }^{38}$.

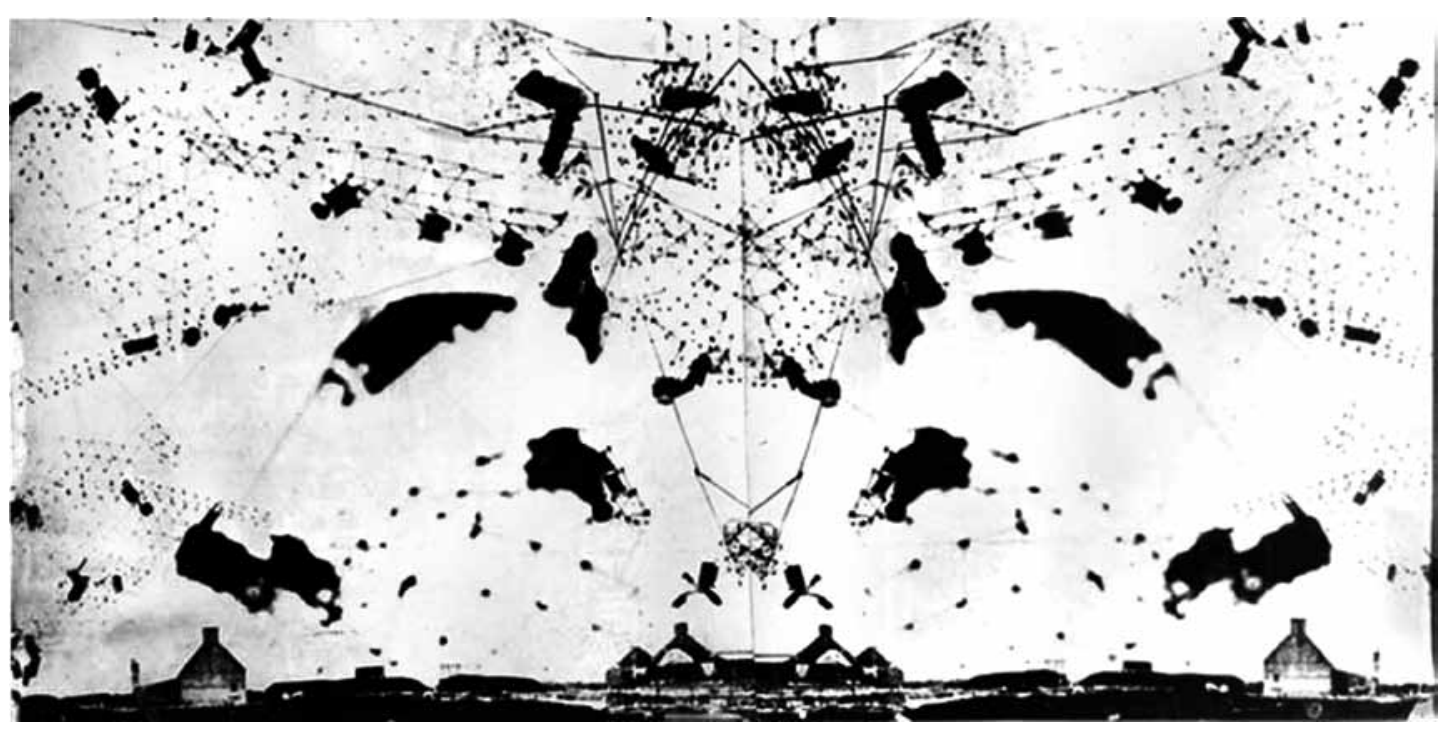

Fig. 5 Dream City Project. Archigram Archival Project. 1963 
ACTOS 5 Y 6 ESCENARIOS A ESCENA. EN EL DELTA TRAGICÓMICO

\author{
Si la modernidad fue la era de \\ los proyectos, la posmoderni- \\ dad se muestra como la era de las \\ reparaciones.
}

(Sloterdijk, 2015:67)

En la factoría cultural de la nueva «sociedad» se liberarán más fuerzas de ensoñación y de anhelo de las que jamás pueden ser integradas mediante redistribución de productos y oportunidades vitales en mundos de expresión dominables.

(Sloterdijk, 2015:63)

(ver fig 6)

La sexta edad nos trae

al viejo enflaquecido en zapatillas, lentes en las napias y bolsa al costado; con calzas juveniles bien guardadas, anchísimas para tan huesudas zancas; $y$ su gran voz varonil, que vuelve a sonar aniñada, le pita y silba al hablar. La escena final de tan singular y variada historia es la segunda niñez y el olvido total, sin dientes, sin ojos, sin gusto, sin nada. Acto II, escena VII. Como gustéis

(As You Like It), de William Shakespeare, 1599.

Dado que Dios durmió a cada noche de la creación, para diferir su obra al día siguiente, hizo al sueño divino. Así lo percibe Jean-Luc Nancy en Tumba de sueño. Hay un suspenso de la pala- bra creadora (2013:38) que podría entenderse como una connotación destacada del Stillstand benjaminiano. Sin embargo, el doblez del mundo que se produciría en el tiempo del sueño de Dios, no tiene siempre en sus surrogate humans un cariz ni heroico, ni donador de conocimiento. Toda fantasmagoría tiene su anverso y reverso, posee potencialidad pero también el contemplarse ante el espejo no provee amplitudes ni virtualidades. Antes bien, espectáculo y pseudorelación. En ese reflejo, que es el estallido de miles de otras imágenes disponibles para sustituir a la palabra, hay una felicidad implícita, alcanzable por la satisfacción de concebirse en un receptáculo autógeno logrado por los propios medios (American Dream). Mantiene una dificultad añadida, la de no poder fijar la mirada fuera de uno mismo, en tanto el interior generado es un campo visual con derecho de admisión, regido por medios técnicos de autocomplementariedad (Sloterdijk, 2003:192). Así el mundo, así la ciudad, en esa paridad indisoluble que anunció Koolhaas. Con una sociedad así, la ficción sólo permite una escena con un único personaje: el individuo mismo. La insatisfacción es completa. Habíamos dejado el concepto wish-fulfillment (wunscherfüllung en la terminología de Freud de su Traumdeutung, La interpretación de los sueños) pendiente de resolver. Ahora encaja.

Se trata de la satisfacción o no, de un deseo en el proceso de un pensamiento involuntario, que emerge en sueños, ensoñaciones, como síntomas de neurosis, alucinaciones y psicosis. Todas estas manifestaciones quedaron recogidas en los actos anteriores como una negatividad no positivable, para hacerla una verdadera alternativa. Por ello la abundancia y extensión de las notas ad marginem, intentando no ser fa- 


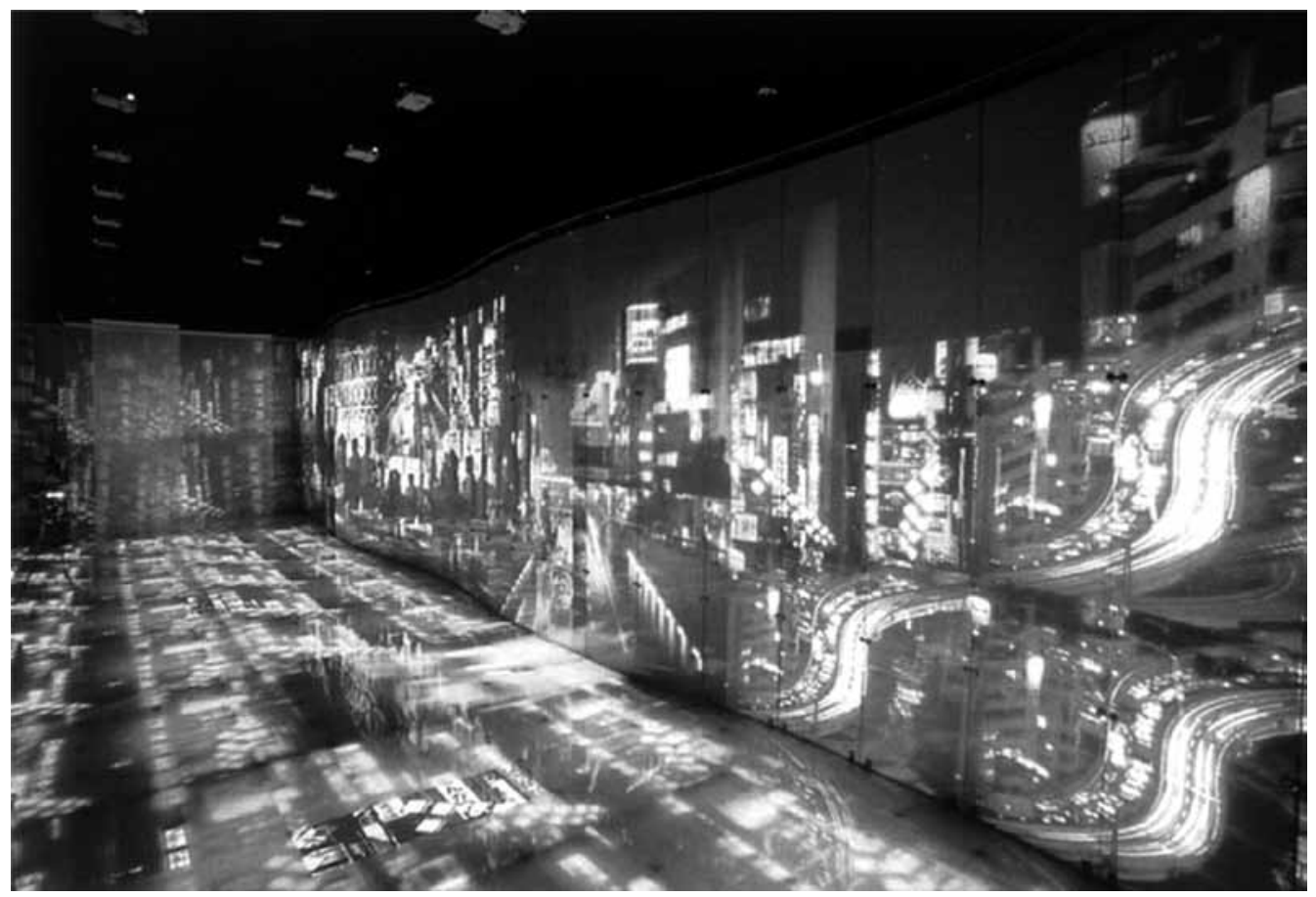

Fig. 6 Dreams Room - Toyo Ito. 1991. London Exhibition Visions of Japan. Victoria and Albert Museum.

gocitadas por un discurso hegemónico, que se escapa del control incluso cuando son escritas con la consciencia de la misma mano que escribe (desde el backstage).

Retóricas de alivio, erudición, persecución de una autonomía formal o de primacía de la representación, nada queda liberado de la sospecha. J-L. Nancy, usando la retórica (anáfora del que), erudición, autonomía y forma, se comporta como el dios que duerme para dar lugar al día siguiente y dice (2013:38): Ya no se pronuncia ningún iQue esto sea!, ya no hay orden que disponga el advenimiento del ser. Hay una obediencia silenciosa a la diferencia del ser: a esa 'nada', a esa 'ninguna cosa', ese ex nihilo que la luz empujó en principio al fondo de las tinieblas en el movimiento mediante el cual brotaba de él. Si fuera necesaria una imagen para esta escena, la de la mariposa atravesada por su alfiler, serviría.

¿Qué es una mariposa ensartada en su expositor?, una belleza trágica, imagen figural final. Sloterdijk (2015), el gran Diógenes inalcanzable por llevar siempre unas 5000 páginas de ventaja, ofrece una imago más descriptiva: un delta gigantesco con corrientes de corrientes que forman un laberinto de venas con diferente velocidad de flujo. En él no hay diferencia entre movimiento y estaticidad, todo corre y se detiene a la vez. A mayor densidad del líquido, mayor concreción de la cultura a la que representa, y que alimenta a una heteroglobalización civilizatoria dominada por el espacio interior del mundo del capital.

Con el aparataje pirotécnico que dará el 
culmen de la felicidad final preparado, las derivas no pueden ser críticas, deshaciendo así el oxímoron del que nos previno Lyotard ${ }^{\mathbb{}}$. Las derivas, sigue Sloterdijk, tienen la misma función que las trayectorias controladas al inicio y que los fracasos, posteriores: por ello sólo profetas nos mantienen a la espera. Y no es mala arquitectura la que presenta el interior de esa sala de espera. No indiferenciaré entre el bien y el mal si invoco las impresionantes simetrías bilaterales del pabellón fantasma de Barcelona de 1929, que daría para un largo debate alado, desgraciadamente truncado por la muerte de Robin Evans.

Tampoco lo haré si mento el Dreamland de Coney Island o el ático de Dream Street en Nueva York, ambos ligados a los sueños de los rascacielos en Delirio de Nueva York. Como proyectos contrapuestos, el DreamCity Project de Archigram contra un Dreamcity en Macao, signado con un parénquima estructural arquitectónico decepcionantemente hecho por la recientemente desaparecida Zaha Hadid. Más allá (¿es posible?), el paroxismo, con el relato del sueño que da lugar al proyecto de renovación del World Trade Center de NY de Ma Yansong, que persiste en tiempo, lugar y forma hasta cobijar la gran nube informacional de Pekín sobre el CCTV de Koolhaas. Una sonrisa se escapa cuando se compara con la Green City de Melnikov, el gran laboratorio del comportamiento humano, nunca construido, donde los edificios tienen los pisos inclinados para que las grandes salas, que albergan una buena cantidad de camas, no precisen almohadas. Gas relajante, temperatura controlada, música ambiental, sueños... que el arquitecto Raymond Hood (Rockefeller Center NY) discutió con el soviético, acompañado por el director escénico del Radio
City Music Hall, interesado en comprar la idea. Visiones críticas como la de Toyo Ito en Dreams Room, un Tokio interior como superficie de inscripción que multiplica los efectos y afectos del primer Daguerrotipo, donde la velocidad de las imágenes no retiene ningún individuo mostrando la vida cotidiana, ni individuo siquiera, ni vida y anticipa así el día después del juicio final, presenciado en exclusiva en la penúltima cámara oscura inventada. Admitiré sin embargo mi predilección por el anti-proyecto de Kengo Kuma para su escenografía en el teatro Chofu de Tokio de 1996. Solicitada la imagen al estudio una más que cortés respuesta me comunica que la imagen de la escenografía no se encuentra entre sus archivos, que su ausencia es la presencia que legitima su concepto.

Este diagrama del delta resulta canónicamente tragicómico, como emocionaría a Harold Bloom. Uno llora de felicidad si recuerda a Jacques, en la obra shakesperiana Como gustéis. Empieza recitando un monólogo que termina con la caducidad de todo, la nada permanece, referido en seis etapas. Pero, señoras y señores, este nuestro gran negocio-paideia recomienza así:
El mundo es un gran teatro, $y$ los hombres y mujeres son actores.
Todos hacen sus entradas y sus mutis $y$ diversos papeles en su vida...

\section{NOTAS}

1 La expresión Theatrum Mundi en la escombrera debe entenderse como la contraposición que exige la lectura de nuestro tiempo, heredera de representaciones de la solidez y permanencia, es decir, de un simbolismo iluminador y transfigurador de los personajes de un periodo como figuras eternas de los conflictos del espíritu. Así lo ha descrito Cacciari en The Unpolitical (2009), y como opuesto al teatro de máscaras, mundo de oportunidades, aventuras, personajes discordantes, teatro de lo transitorio y descompuesto, del interés por lo mundano, permanentemente regresando 
y colapsando. Con tal oxímoron introducimos un argumento que recorrerá nuestros supuestos, de lo moderno a lo postmoderno tratando de alcanzar un reencantamiento del mundo, por usar un término en constelación desde $\mathrm{M}$. Weber, A. Artaud, J. Ritter leyendo al Marquard de la felicidad en la infelicidad de lo moderno, GD. Amendola o J.L. Nancy.

2 Tan solo -sin tilde- se queda uno cuando meramente cae en la cuenta de la ingenuidad de que no hay nada más que lo dicho al invocar un término, concepto, cláusula, etc. Digámoslo ya: la forma y lo dicho, conforme a lo que trata de explicitarse, son aquí, si no lo mismo, homotéticos y, justamente al referirse al encargo de constituir el oxímoron lyotardiano de las derivas críticas postmodernas, el backstage es tan vasto, que sólo invocar al primer Bloom del Cuarteto de Yale, remueve décadas de diatribas por la dis-locación del pensamiento arquitectónico. Pensamiento que, bastarda entelequia a repudiar como teoría, no supo si espacializaba literatura, filmaba construcción, o filosofaba geografías, si era necesario saberlo, o si su autonomía legitimaba realizar todo ello, mientras todo ello-French Theory-' legitimaba su autonomía. Baste ver el par de páginas mal contadas que dedica el libro de 2005 de François Cusset (de casi 400 páginas) a explicar la arquitectura, para evidenciar la lateralidad que muestra el trabajo de los arquitectos en la sociedad actual.

3 Debe recordarse el esfuerzo de Humberto Maturana ( $L a$ realidad: ¿Objetiva o construida? Fundamentos biológicos de la realidad) por poner la cuestión de lo real en el registro de lo urgente, y que Sloterdijk (Los latidos del mundo), por otros motivos, igualmente lo prioriza al exclamar que quien es soberano es el que define el principio de la realidad, pero mediante una hermenéutica de lo real. Clásico sería citar la hiperrealidad de Baudrillard (El crimen perfecto), pero mantenemos la esperanza de que existe si no una alternativa, al menos un principio de negatividad contrarrestante.

4 En su obra Las Nubes del siglo V, Aristófanes denuncia los métodos sofistas. La versión que se conserva es una adaptación en la que los espectadores también forman parte de la escena, reprochados por no conceder a la obra un carácter triunfador, cosa que fue lo que pasó con la primera versión y dio motivo a la reescritura de la segunda. En nuestro tiempo, carente de alternativas, todos los contendientes acuden a los mismos argumentos, razonamientos y fuentes, pretendiendo ser distintos, afianzando ya no las políticas que se defienden, sino un territorio de charlatanería donde se rizan hasta el embeleso meramente los factores más demagógicos.

5 Permítasenos seguir jugando con palabras y sus inversiones, su reversos, lo que luego llamaremos simetrías bilaterales. Cada una de ellas invoca a tantas otras, algunas más implícitas que otras, y su puesta en relación abisma los sentidos. Nos parece que nuestro tiempo contempla esta singu- laridad que, aunque concurren suficientes evidencias como para pensar que se poluciona informacionalmente y los peer reviewers alegarían inadecuación académica, cabría sentir que una aclaración continua de cada argumento empobrece el ejercicio que ha de hacerse con cada texto: perseguir fuentes, rastrear presencias, extraer diagramaciones de lo invisible. San Agustín era conocido, entre otros hechos, por ser un lector de introspección, que no dependía de leerse a sí mismo oralmente el texto, como se acostumbraba en su época. Llevado a nuestro hilo argumental, significa que el relato hecho novella como resistencia al mal físico de la epidemia de la peste, conjura por la palabra lo mundano de la vida para elevarla a il ben vivere, rasgo de modernidad. Todas estas ideas pueden más ampliamente verse descritas en el pequeño libro de Sloterdijk hecho por encargo del gobierno de Extremadura, en España, que lleva por título El Reino de la Fortuna (2013, Fundación Ortega Muñoz). Extendido a ello, Artaud (2001:29) recuerda al San Agustín escritor de La ciudad de Dios (426 d.C.) que en analogía del cuerpo infectado de peste que no deja ver síntoma en los órganos afectados, el teatro corrompe no sólo el alma de un cuerpo sino a un pueblo en su conjunto, debiendo destruirse cada piedra de tales lugares impíos. Algo de cierto debe darse cuando los griegos hacían teatros abiertos al paisaje y los romanos los cerraban para los espectáculos sangrientos. Circo romano y sociedad del espectáculo moderna se vinculan por genealogías de ramas primarias.

6 Mertins publicó ese artículo en Anycorp, Any 14. 1996, pero también el mismo año de su muerte, en Modernity unbound. AA Publications. London. 2011, que reseñamos en nuestra bibliografía.

7 Los detalles son importantes, aunque en este momento podrían ser distractivos, por lo que se comentan brevemente en esta nota aparte, pudiendo ampliarse leyendo los trabajos en web del profesor de Standford Nicholas Jenkins. Daguerre se encuentra entre 1832 y 1835 en bancarrota con su negocio de exhibición de dioramas, que abre en 1822 con dos tableaux, La vallée de Sarnen y La Chapelle de la Trinité dans l'Église de Canterbury pintados por Daguerre. Antes de la destrucción en 1839 por un incendio del edificio donde tenía el laboratorio y el diorama, se mostraron 21 tablas pintadas por Daguerre y Sèbron.

En ese tiempo, Daguerre perfeccionó por casualidad al encerrar en un armario la solución química que impregnaba el proceso de impresión, reconoció -a regañadientes- el trabajo previo de Niépce en ese proceso, que él llamó la héliographie, pagando a su hijo derechos, y recibió el apoyo del político y científico François Arago para una subvención estatal a partir de la cual popularizar el invento. Seguir, para más precisiones y datos, esta dirección web: www.midley.co.uk/ Igualmente ha de consultarse obligadamente de Gisèle Freund, La fotografía como documento social, de 1974, traducido por GG desde 1993 en sucesivas reediciones. W. 
Benjamin hace una reseña de los trabajos de Freund en 1938 (inserta en Sobre la Fotografía, Pre-Textos, $4^{\text {a }}$ edición de 2008) sobre la historia de la fotografía y del retrato desde 1780 hasta el fin del siglo XIX.

8 Exactamente, dice Agamben: No podría figurarme una imagen más adecuada del Juicio Universal. La muchedumbre de los humanos -incluso la humanidad entera está presente- pero no se ve, porque el juicio concierne a una sola persona, a una sola vida: esa, precisamente, y no otra. ¿Y de qué modo esa vida, esa persona ha sido elegida, arrapada, inmortalizada por el ángel del Último Día, que es también el ángel de la fotografía! ¡En el gesto más banal y ordinario, en el gesto de hacerse lustrar los zapatos! En el instante supremo, el hombre, todo hombre, es remitido para siempre a su gesto más ínfimo y cotidiano. Y sin embargo, gracias al objetivo fotográfico, el gesto se carga del peso de una vida entera; ese comportamiento irrelevante, hasta bobo, compendia y condensa en sí el sentido de toda una existencia.

9 No es cierto, pueden verse rastros de niños, el propio limpiabotas, etc., como puede indagarse con cierta facilidad y agudeza visual, pero durante años fue la persona que fijó la imagen que representó a la Humanidad vista por ella misma, como un exterior.

10 Los edificios de esta zona de París donde se tomaron estas primeras fotografías fueron casi completamente arrasados, las viejas calles fueron destruidas y se construyeron nuevas durante la haussmannización del distrito y la creación de plaza de la República entre 1854-1879. Para algunos investigadores, el sitio del diorama de Daguerre en el actual París quedaría aproximadamente en el lado sur de la rue Léon Jouhaux, en la esquina norte de la plaza de la República.

11 Para Déotte, una superficie de inscripción es un acontecimiento necesariamente técnico y un aparato, en la terminología benjaminiana, un appareil. El conjunto de las superficies de inscripción se denomina, consecuentemente, cultura.

12 Pessoa escribió: El misterio nunca se transparenta tanto como en la contemplación de las cosas pequeñitas que, al no moverse, son perfectamente transparentes al misterio, aquietándose hasta dejarlo pasar. (2014: 73)

13 Puede perseguirse una conectividad de estos presupuestos si se consultan los trabajos del propio Batchen, de Jonathan Crary y de M. Foucault.

14 Según C. Castoriadis, los imaginarios son radicales representaciones o significaciones sociales saturadas de atributos aglutinadores donde prima lo discontinuo, lo inesperado, lo no ordenable. Los imaginarios demarcan y allanan lo pensable en un momento histórico o en un período cultural. A diferencia de la ideología (anclada en clases y grupos sociales), los imaginarios impregnan la totalidad de la estructura e instituciones sociales. (Ver para quienes quieran acortar lecturas y demorar ir a los libros completos, el breve texto explicativo de Castoriadis, El imaginario social instituyente, Zona Erógena, 37. 1997).

15 Autores como Starobinski o Augé han recogido en sus textos fragmentos de este primer verso de los Tableaux $\mathrm{Pa}$ risiens. La version más reconocida en inglés es la de William Aggeler, The Flowers of Evil (Fresno, CA: Academy Library Guild, 1954), que personalmente me es menos cara.

No hay traducción al español que acabe dando métrica y rima cercana al original en francés original pero la crítica especializada valora la que se expone aquí en su verso completo, de Luis Martínez de Merlo para Cátedra:

Paisaje / Quiero, para crear castamente mis églogas, / igual que los astrólogos, junto al cielo acostarme,/ y entre sueños, vecino del campanario, oír / sus solemnes salmodias lloradas por el viento / La barbilla en las manos, desde mi alta buharda / contemplaré el taller que canta y charlotea;/ chimeneas y torres, mástiles de la urbe, / los cielos que hacen soñar de eternidad.

16 Recuérdese que Garnier se sintió fascinado por la novela de Zola Travail y dispuso el exterior de la Sala de Reuniones de su Cité Industrielle compuesto por citas extraídas de ese libro y grabadas en la fachada.

17 El traductor de Baudelaire bajo el que nos amparamos, Martínez de Merlo, dice en uno de sus comentarios que los Cuadros Parisinos son un cuestionamiento del poeta que denuncia una realidad detestable, la de la gran ciudad. Y la equipara a la que sería hecha por los pintores o los modernos fotógrafos. Tal cosa es Spleen de Paris, conduciendo hacia un supuesto ideal de Paris que nadie llegó a conocer.

18 Didi-Huberman (2010: 133), a propósito de Warburg y su Bilder-Atlas Mnemosyne, datará a comienzos del siglo XVII el empleo de la palabra explosión en la lengua francesa del Renacimiento como invasión súbita e inesperada de síntomas. Se trata de una manifestación que destella, ligada a una destrucción. Es, una paradójica visión del mundo, en el sentido pues de Benjamin.

19 Adorno no estuvo de acuerdo y exigía ser mejor dialéctico a quien efectivamente no lo era, por ser mejor un apasionado de las transformaciones que conservan medidas y sus relaciones de proximidad, como demuestra pensar sobre lo lejano y lo cercano, esto es, pensar en topologías. El autor de la dialéctica negativa, no da crédito a que la superestructura esté siempre medio siglo atrasada con respecto al desarrollo de la infraestructura, como argumentaba Benjamin. Llevado más cercanamente a la arquitectura, Déotte (2013:18) deja entrever sin aseverar más categóricamente que a partir de la relación de Benjamin con Giedion se funda un enfrentamiento entre infraestructura (de la producción en Marx se pasa la técnica de la construcción) y la superestructura, en sentido cultural, cuya manifestación más evidente se tiene en los comportamientos de lo urbano (Spleen, 
Flâneur, Badaud, Dandy, Bovarismo y Ennui...)

20 Merrifield, Andy. The New Urban Question, London: Pluto Press, 2014.

21 Debe verse para su mayor comprensión la tercera parte del libro de Christine Buci-Glucksmann, La folie du voir - Une esthétique du virtuel, Paris, Galilée, 2002.

22 Berkeley, George, Essay Towards a New Theory of Vision,1709. http://www.gutenberg.org/files/4722/4722h/4722-h.htm

23 Calasso (2011:27) apunta que Baudelaire era un estudioso de la profundidad, puramente en sentido espacial. Los

de polarizar Europa contra Norteamérica, impidiendo ver más allá. Los documentales de Adam Curtis, en particular, All Watched Over by Machines of Loving Grace ,BBC (2011) y el dirigido por Jared P. Scott, Kelly Nyks y Peter Hutchison, titulado Réquiem por el sueño americano. Noam Chomsky y los principios de concentración de riqueza y poder, (2016), son recomendados en el mismo sentido.

25 No hay nada más cosmopolita que lo eterno, ha dicho Baudelaire. (Calasso, 2011: 150)

26 La Isotopía organiza distintos estratos de la identidad, mientras que la alotopía organiza distintos estratos concomitantes de diferencia.

27 Para más referentes en lo tocante a sueño y arquitectura, objeto de mi programa de Historia, Teoría y Composición Arquitectónicas de $5^{\circ}$ año de la ETS arquitectura de Sevilla, sugeriría ver mi Relatos de lo extremo: acuerdos entre sueños y despertares de ciudad futura. En, Cidades. 2015. Vol. 11. Núm. 19. São Paulo.

28 Conviene atender no sólo para la melancolía, sino para el encuentro del XIX con el XX, todo el excelente trabajo de Roberto Calasso La Folie Baudelaire, de 2011.

29 Sloterdijk (2000:49) lo remacha con amartillado musical: La imagen de la doble escena podría muy bien caracterizar la muy particular relación de Nietzsche con el público y la posteridad: en una, el pensador se expone y se implica, en la otra, sus pensadores coetáneos y los seguidores prueban la posible transmisión de las verdades del protagonista sobre sí mismos.

30 No se nombra como Teatro Total en el sentido de obra de Arte Total (Gesamtkunstwerk) para no invocar un asunto diferente que corre en paralelo.

31 El libreto imprescindible sobre el sueño de la catedral es de nuevo una amalgama de información y tiempos otros que explica con rotundidad Simón Marchán en Contaminaciones Figurativas (1986:65) y que por extensión no cabe aquí más que su recomendación de uso.

32 Con la palabra uncanny, Freud define un sentimiento o tableaux, bastidores teatrales inagotables, incrementan el momento de la existencia, los iluminan, como el despertar védico de la Bodhi, como el opio provoca, cuando la dosis natural que cada hombre lleva no es suficiente. Así se espacializa el pensamiento (Denkraum, diría Warburg), cuando el espacio, analogía del tiempo, se entreabre en una sucesión de planos en los que las figuras particulares se recortan con una nitidez embriagadora y casi dolorosa.

24 Ver En el mundo interior del capital de Sloterdijk, alrededores de la página 404, sobre el sueño americano y el delirante libro de 1993 de Edward N. Luttwak: The Endangered American Dream. How to Stop the United States to Become a Third World Country and How to Win the Geo-Economic Struggle for Industrial Supremacy. J. Rifkin (El sueño europeo, 2004) es obligado igualmente por lo bizco que se queda uno al tratar

sensación que nos desvela algo que no es nuevo aunque extraño, algo familiar y profundo, arraigado en nuestra mente, pero reprimido, que su dificultad de afloramiento sólo prueba su represión. Algo que es usado por el historiador de la arquitectura contemporánea, Anthony Vidler, como apertura a la relación posible entre lo surreal y lo arquitectónico. The Architecture of the Uncanny: The Unhomely Houses of the Romantic Sublime. Anthony Vidler. Assemblage, No. 3 (Jul., 1987), pp. 6-29

33 Giacomo Leopardi (1798-1837) lo aclarará más prontamente: Ver, para el pensamiento de la poesía, es buscar aquel confín donde el paisaje muestra otro lado y este otro lado no es solo la onda de la correspondencia que une la línea de los montes con el sonido del viento... Este más allá de, es la onda de una metamorfosis que lleva el paisaje hacia la palabra... Porque la cuestión para el poeta es cómo coger en el nombre la aparición y la desaparición de las cosas.

Antonio Prete, Detrás del paisaje. Sobre "otra mirada" en Leopardi y Baudelaire, en AA.VV. Romanticismo. In nuovo sentimiento della natura. Electa: Milano 1993, pp. 391-402. la cita de Leopardi es del Zibaldone, su párrafo 4418, de 30 de noviembre, 1828. Agradezco A JR Moreno Pérez esta referencia, así como la del artículo de JM Rovira sobre Tafuri. 34 Psyché es, para los griegos, no por casualidad, mariposa. 35 Ver Ninfas, de Giorgio Agamben, entre las páginas 29 y 44 .

36 Para otra ocasión se deja en suspensión una mayor alusión a la Tafel 46 de Aby Warburg en el Mnemosyne-Bildatlas, titulada Ninfa Eilbringitte en el círculo de Tornabuoni.

37 Una noche, Zhuangzi soñaba con ser una mariposa, una mariposa feliz, mostrando y haciendo las cosas a su antojo, sin darse cuenta de ser Zhuangzi. De repente se despertó, somnoliento, Zhuangzi de nuevo. Y no podía decir si era 
Zhuangzi el que había soñado la mariposa o la mariposa soñado Zhuangzi. Lacan, Seminario XI. 1964.

\section{BIBLIOGRAFÍA}

A,Giddens Z. Bauman... [et al.] ; Josetxo Beirain (comp.). 1996. Las consecuencias perversas de la Modernidad: Modernidad, Contigencia y Riesgo. Barcelona: Anthropos.

Agamben, Giorgio. 2005. Profanaciones. Barcelona : Anagrama.

Agamben, Giorgio. 2010. Ninfas. Valencia : Pretextos.

Artaud, Antonin. El teatro y su doble. Barcelona: Edhasa.

Augé, Marc. 1998. La guerra de los sueños: Ejercicios de etno-Ficción. Barcelona:Gedisa.

Batchen, Geoffrey. 2004. Arder en deseos: La concepción de la totografía. Barcelona : Gustavo Gili,.

Baudelaire, Charles. 2007. Las flores del mal. Madrid: Cátedra.

Benjamin, Walter. 1982. Infancia en Berlín hacia 1900. Madrid: Alfaguara.

Benjamin, Walter. 2011. Libro de los Pasajes. Madrid : Akal.

Benjamin, Walter. 1989. Discursos Interrumpidos. Madrid: Taurus.

Berkeley, George. 1980. Ensayo de una nueva teoría de la visión. Buenos Aires: Aguilar.

Bloom, Harold. 2009. El cánon occidental: La escuela y los libros de todas las epocas Barcelona : Anagrama.
38 Aunque se pueden encontrar más referencias a la deriva en Lyotard, se ha usado el libro A partir de Marx y Freud. 1975. Fundamentos. Madrid.

Brenner, Neil. 2013. Tesis sobre la urbanización planetaria. Nueva sociedad, 243. 38-66.

Buci Glucksmann, Christine. 2002. La folie du voir: Une esthétique du virtuel. Paris : Galilée.

Buck-Morss, Susan. 2004. Mundo soñado y catástrofe: La desaparición de la utopía de masas en el Este y el Oeste. Boadilla del Monte (Madrid): A. Machado Libros.

Cacciari, Massimo. 2006. Quid Tum. DC PAPERS, Revista de Crítica y Teoría de

la Arquitectura. Departament de Composició Arquitectònica.

Cacciari, Massimo. 2009. The Unpolitical: On the radical critique of political reason. New

York: Fordham University Press.

Calasso, Roberto. 2011. La Folie Baudelaire. Barcelona:Anagrama.

Castoriadis, Cornelius. 1989. La institución imaginaria de la sociedad. Barcelona : Tusquets.

Crary, Jonathan. 2013. 24/7: Late capitalism and the ends of sleep. London: Verso Books.

Crary, Jonathan. 2008. Las técnicas del observador: Visión y modernidad en el siglo XIX. Murcia : Cendeac.

Cuesta Abad, José Manuel. 2004. Juegos de duelo: La historia según W.Benjamin. Madrid: Abada. 
Cusset, François. 2005. French Theory : Foucault, Derrida, Deleuze \& cía. Y las mutaciones de la vida intelectual en Estados Unidos. Barcelona : Melusina.

Déotte, Jean-Louis. 2013. La ciudad porosa: Walter Benjamin y la arquitectura. Santiago de Chile : Metales Pesados.

Didi Huberman, Georges. 2007. La Imagen Mariposa.Barcelona : Mudito \& Co.

Ferrater Mora, José. 2009. Diccionario de Filosofía. Barcelona: Ariel.

Finkielkraut, Alain. 2008. Los latidos del mundo : Diálogo Finkielkraut-Sloterdijk. Buenos Aires: Amorrortu.

Freund, Gisèle. 2008. La Fotografía como documento social. Barcelona : Gustavo Gili.

Gardner, Martin. 1990. The new ambidextrous universe: Symmetry and asymmetry from mirror reflections to superstrings.

Ginzburg, Carlo. 1999. Mitos, emblemas e indicios : Morfología e historia. Barcelona: Gedisa.

Han, Byung-Chul. 2015. El aroma del tiempo : Un ensayo filosófico sobre el arte de demorarse. Barcelona :Herder.

Harvey, David. 2008. Paris, capital de la modernidad Madrid: Akal.

Illich, Ivan. 1989. H2O y las aguas del olvido. Madrid: Cátedra.

Innerarity Grau, Daniel. 1988. Hacia una ecología de la razón: consideraciones sobre la filosofía de la postmodernidad. Anuario filosófico.

Jay, Martin. 2007. Ojos abatidos : La denigración de la visión en el pensamiento francés del siglo XX.Madrid. Akal.

Nancy, Jean-Luc. 2013. Tumba de sueño. Madrid:Amorrortu.

Kroker, Arthur. 2014. Exits to the posthuman future. Wiley.

Lahiji, Nadir. 2014. The missed encounter of radical philosophy with architecture. London : Bloomsbury.

Le Goff, Jacques. 2015. La Civilización del Occidente medieval.Barcelona : Paidós.

Lévy, Pierre. 1999. ¿Qué es lo virtual?. Barcelona: Paidós.

Marx, Karl. 2009. Introducción general a la crítica de la economía política. Madrid : SXXI.

Merrifield, Andy. 2014. The new urban question. London :PlutoPress.

Mertins, Detlef. 2011. Modernity unbound: Other histories of architectural modernity. London: Architectural Association.

Onfray, Michel. 2009. El sueño de Eichmann precedido de Un kantiano entre los nazis. Barcelona : Gedisa.

Pessoa, Fernando. 2013. Libro Del Desasosiego. Barcelona: Seix Barral.

Rovira, Josep María. 2006. Quid Tum. DC PAPERS, Revista de Crítica y Teoría de la Arquitectura. Departament de Composició Arquitectònica.

Sloterdijk, Peter. 2013. Muerte aparente en el pensar: Sobre la filosofía y la ciencia como ejercicio. Madrid : Siruela. 
Sloterdijk, Peter. 2015. Los hijos terribles de la edad moderna: Sobre el experimento antigenealógico de la modernidad. Madrid: Siruela.

Sloterdijk, Peter. 2014. Fiscalidad voluntaria y responsabilidad ciudadana: Aportaciones a un debate filosófico sobre una nueva fundamentación democrática de los impuestos. Madrid:Siruela.

Sloterdijk, Peter. 2007. En el mundo interior del capital : Para una teoría filosófica de la globalización. Madrid : Siruela.

Sloterdijk, Peter. 2012. Has de cambiar tu vida : Sobre antropotécnical. Valencia : PreTextos.

Sloterdijk, Peter. 2013. El reino de la fortuna. Badajoz: Fundación Ortega Muñoz.
Sloterdijk, Peter. 2007. Derrida, un egipcio. El problema de la pirámide judía. Madrid: Amorrortu.

Sloterdijk, Peter. 2000. El pensador en escena : El materialismo de Nietzsche. Valencia : PreTextos.

Sloterdijk, Peter. 2003. Esferas. I, Burbujas : Microsferología. Madrid : Siruela.

Starobinski, Jean. 1997. La Mélancolie au miroir : Trois lectures de Baudelaire. Paris : Julliard.

Tafuri, Manfredo. 1984. La esfera y el laberinto : Vanguardias y arquitectura de Piranesi a los años setentai. Barcelona: Gustavo Gili.

Zizek, Slavoj. 2010. El sublime objeto de la ideología. México : Siglo XXI. 